\title{
Effect of Police Confinement Training Period on Respiratory Muscle Power and Hemoglobin in Khartoum State, Sudan
}

\author{
Sajda A Elmohseen ${ }^{1}$, Osama A Ibrahim², Esam Mohamed Abdalla ${ }^{3}$, Ibrahim A Ali ${ }^{1 *}$ and Omer A Musa ${ }^{1}$ \\ ${ }^{1}$ Department of Physiology, The National Ribat University, Sudan \\ ${ }^{2}$ Faculty of Police Science and Law, Sudan
}

${ }^{3}$ Department of Physiology, Gezira University, Sudan

Submission: April 25, 2018; Published: May 03, 2018

*Corresponding author: Ibrahim A Ali, Department of Physiology, The National Ribat University, Khartoum, Sudan, Email: hemamedicine@gmail.com

\begin{abstract}
Introduction: Adequate aerobic capacity and muscle strength are essential elements to perform the activities that are required from professional soldiers \& officers to optimize their peak performance \& maintain physically demanding tasks. The newly recruited police officers will be subjected to 6_8 week's confinement in which they will have a training program including exercise \& initial police training. The objective of this study was to assess the respiratory muscle power, blood pressure and hemoglobin during this period.
\end{abstract}

Method: This was a cross sectional study conducted during the period from July to September 2017 in Soba, faculty of police science and law, Khartoum, Sudan. Eighty-one policemen trainee were randomly selected, aged between 20 and 30 years underwent evaluation before \& after the confinement period (40 days). Maximal respiratory pressure (MEP and MIP) was measured using respiratory pressure meter for respiratory muscle power. Hemoglobin, pulse \& blood pressure was also measured.

Results: The mean values of MEP \& MIP were significantly higher after the end of the confinement period $(\mathrm{P}>0.05)$. Also there was significant change in the mean of hemoglobin before \& after the confinement period $(\mathrm{p}=0.03)$. There was no change in pulse $\&$ blood pressures.

Conclusion: Police training confinement improves respiratory muscle power \& hemoglobin level.

Keywords: Police training; Respiratory muscle power; Hb level in police training

\section{Introduction}

Exercise is a stressful situation that produces marked changes in body functions including the respiratory system. The physical inactivity is directly related to morbidity and mortality from many diseases [1]. Therefore, physical training is one of the major bases for good health and wellbeing and currently globally recommended [2]. During exercise the body's demand for oxygen increases as the breathing must also rise. This requires numerous muscles surrounding the lungs to contract in a highly coordinated manner. As the intensity of exercise increases, the respiratory muscles contract more forcefully and quickly to keep pace with the increase in oxygen demand. Training of the respiratory muscles increases their strength and improves lung function and was found to reduce the severity of obstructive sleep apnea in cervical spinal cord injury and improves breathing pattern in patients with COPD $[3,4]$.

Maximal inspiratory pressure (MIP) and maximal expiratory pressure (MEP) are useful indices for assessment of respiratory muscles performance in adults as well as in children [5]. Several cross-sectional and cohort studies have shown significant improvement of lung function as a result of exercise in both children and adolescents [6-9]. However, measurement of respiratory muscles strength has not been widely investigated in relation to physical training. In this context, the present study aimed at assessing pulmonary function as well as respiratory muscles strength among policewomen trainees compared to healthy untrained sedentary group of medical students.

The common physiological changes that alter the body during exercise are the cardiopulmonary changes; mainly they include increase in pulmonary ventilation (breathing) which directly proportionate to the intensity \& metabolic needs of exercise. Breathing may increase from typical resting rate of 15 breaths per min up to 40-50 breath per minute. As the intensity of exercise continue to increase a person reaches a maximum point above which oxygen consumption will not increase any more. This point is known as VO2 MAX and can be improved by long term endurance by increasing aerobic enzyme activity \& improving glycogen stores in muscle. 
A previous study was done by Awad et al. [10] 2012 on the effect of police training on some cardiopulmonary \& hematological parameters in Khartoum state, Sudan. The aim of their study was to investigate the effect of training of male police officers on the spirometeric lung function test parameters, respiratory muscle power, blood pressure, hemoglobin \& white blood cells. A cross sectional study conducted during the period from October to December 2012, in which 59 policemen trainee were randomly selected with another 30 medical students as control. The maximum inspiratory and expiratory pressure (MIP\&MEP) were found to be significantly higher in police trainee MIP 106.9+28.17 $\mathrm{cmH} 20(\mathrm{P}=0.005)$ and MEP 137.51+ $31.68 \mathrm{cmH} 20(\mathrm{P}=0.000)$ compared to control MIP 88.13+30.96 $\mathrm{cmH} 2 \mathrm{o}$ and MEP 103.57+ $29.9 \mathrm{cmH} 2 \mathrm{O}$. There was significant increase in $\mathrm{Hb}$ value, the mean of $\mathrm{Hb}$ in policemen was $14.5 \mathrm{~g} / \mathrm{dl}$ compared to control group $13.7 \mathrm{~g} / \mathrm{dl}$.

Another study done by Segizbaeva MO et al. [11] on the effect of inspiratory muscle training on resistance to fatigue of respiratory muscles during exhaustive exercise. Daily inspiratory muscle strength training was performed for 3 weeks in 10 male subjects .the study found that inspiratory muscle training results in a significant increase in MIP (+18\%) [11]. A study done by Branch Rasht, Islamic Azad University 2011 on the effect of one period of training on hemoglobin, hematocrit and RBCs of athlete girls. In which13 athlete girls were selected none randomly for 8 weeks of training.They found that there was significant decrease in $\mathrm{HB}$ after the period of training $(\mathrm{P}=0.045)$ [12]. Some of the studies suggest that in endurancetrained athletes hematological parameters such as hematocrit, hemoglobin concentration, and red blood cell (RBC) count are reduced, mainly due to exercise-induced plasma volume expansion, which sets in within a few days of exercise training [13]. One of the studies suggests that the physical training itself has no significant effect on hematological variables in athletes compared with controls. The specific type of duration of training is of major importance in adaptation of the RBC system and the iron metabolism [14].

Some of the studies performed to assess the influence of duration of training on hematological parameters among runners and compared them with age- and sex-matched controls group. They found that there is an increase in the counts of RBC and hemoglobin concentration in the runners compared to controls group [15-18]. The aim of this study was to investigate the effects of police training during confinement period on respiratory muscle power, blood pressure, pulse and hemoglobin.

\section{Methods}

A cross sectional descriptive study was conducted during July to September 2017 in the faculty of police sciences and law, Soba, Khartoum state, Sudan. Study population included 81 newly recruited subjects. The subjects were healthy with no symptoms of present illness aged between 20_30 years. Any subject with a history of cardiorespiratory diseases \& acute respiratory infection were excluded from the study. The students were informed by consent to get sociodemographic data. Their weight was recorded without shoes on a weighing scale. Pulse was counted \& blood pressure measured in a sitting position with a sphygmomanometer. Respiratory muscle power was measured by respiratory pressure meter (RPM), in measuring the maximum expiratory pressure (MEP) the subject was asked to inhale to the total lung capacity (TLC) \& then exhale with as much effort as possible through the controlled leak of the meter for at least 3 seconds. The reading displayed was the maximum average expiratory pressure over 1 second. While the maximum inspiratory effort (MIP) was conducted by having the subjects expire to a residual volume (RV) \& then perform a maximum inspiratory maneuver. The reading displayed was the maximum average inspiratory pressure over one second. Blood sample was collected into a container tube containing K3_EDTA (anticoagulant), and HB was measured using sysmex KX-21 automated hematology.

\section{Results}

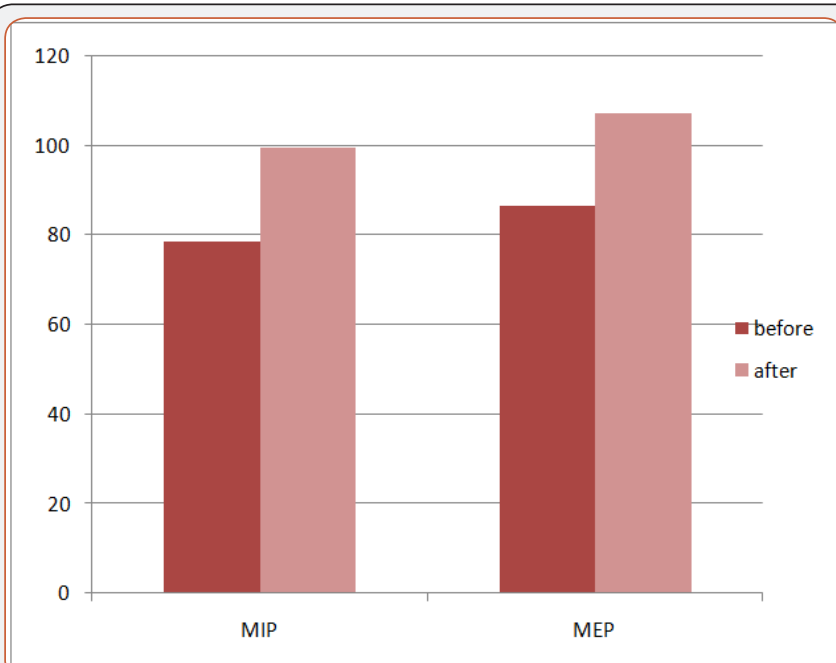

Figure 1: MIP \& MEP before and after the period of Confinement.

Table 1: MEP \& MIP of the policemen before and after confinement.

\begin{tabular}{|c|c|c|c|}
\hline $\begin{array}{c}\text { Respiratory } \\
\text { Muscle Power } \\
\text { Parameter }\end{array}$ & $\begin{array}{c}\text { Before } \\
\text { Confinement }\end{array}$ & $\begin{array}{c}\text { After } \\
\text { Confinement }\end{array}$ & P Value \\
\hline $\begin{array}{c}\text { Mean MIP } \\
\left(\mathrm{cm} \mathrm{H}_{2} \mathrm{o}\right)\end{array}$ & 78.49 & 99.75 & 0.001 \\
\hline $\begin{array}{c}\text { Mean MEP } \\
\left(\mathrm{cm} \mathrm{H}_{2} \mathrm{o}\right)\end{array}$ & 86.49 & 107.41 & 0.02 \\
\hline
\end{tabular}

The average age of the studied subjects was 25.5. The mean weight of participants was $85+7 \mathrm{Kg}$ before training and $75+7$ Kg after confinement period. The mean length of the participant was $180+9 \mathrm{~cm}$ before and after confinement period. Our study found that the respiratory muscle powers measured by MIP \& MEP were significantly increased after the confinement period (Table 1 \& Figure 1). There was significant change in mean blood hemoglobin level before \& after confinement as the mean 
HB level was found to be $11.75 \mathrm{~g} / \mathrm{dl}$ before confinement period compared to $11.88 \mathrm{~g} / \mathrm{dl}$ after i. There was no change in pulse \& blood pressure. After the end of confinement period (The systolic mean pressure $=117.4 \mathrm{mmHg}$ ) (diastolic mean pressure $=80.74 \mathrm{mmHg}$ ) (pulse mean=84.74 beat $/ \mathrm{min}$ ).

\section{Discussion}

This study showed that the mean value of respiratory muscle power (MIP \& MEP) were significantly higher after the end of confinement period MIP $(\mathrm{p}=0.001) \& \operatorname{MEP}(\mathrm{P}=0.02)$ these finding did not differ much from the previous studies. A study done by Kamal et al. [10] and Segizbaeva et al. [11]. Our study showed that there was increase in hemoglobin level after the end of confinement period could be due to good nutritional status, or exercise induced hemo concentration as a result of fluid transfer from the blood to interstitial space. This differ from a previous study done by Islamic Azad University 2011 [12] suggested aerobic training decrease HB, HTC and RBCs in athlete. In our study there was no change in systolic \& diastolic blood pressure after the end of confinement period. This differed from a study done by Kamal et al. [10] they found significant decrease in systolic blood pressure $(\mathrm{P}=0.001)$ and diastolic blood pressure $(\mathrm{P}=0.007)$ in policemen.

\section{Conclusion}

Physical training and exercise during the confinement period improved the pulmonary function and respiratory muscle power in police trainees after 40 days of training.

\section{Acknowledgements}

Authors would like to thank the Police College trainees at faculty of police science and law, The National Ribat University, Khartoum, Sudan, from which data used in this study were gained.

\section{Ethical Approval}

The study was approved by the Institutional Ethics Committee.

\section{References}

1. US (2010) Department of Health and Human Services. Office of Disease Prevention and Health Promotion, Healthy people 2020, New York, USA.

2. World Health Organization (2010) Global recommendations on physical activity for health. World Health Organization Press, Geneva, Switzerland, USA.
3. Boswell Ruys CL, Lewis CR, Gandevia SC, Butler JE (2015) Respiratory muscle training may improve respiratory function and obstructive sleep apnoea in people with cervical spinal cord injury. Spinal Cord Ser Cases 1: 15010.

4. Charususin N, Gosselink R, McConnell A, Demeyer H, Topalovic M, et al. (2016) Inspiratory muscle training improves breathing pattern during exercise in COPD patients. Eur Respir J 47(4): 1261-1264.

5. Rocha MA, Pinto ML, Couto C, Bernhoeft M (2011) Maximal respiratory pressures among adolescent swimmers. Rev Port Pneumol J 17(2): 6670.

6. Berntsen S, Wisløff T, Nafstad P, Nystad W (2008) Lung function increases with increasing level of physical activity in school children. Pediatr Exerc Sci 20(4): 402-410.

7. da Silva BG, Wehrmeister FC, Quanjer PH, Pérez Padilla R, Gonçalves $\mathrm{H}$, et al. (2016) Physical activity in early adolescence and pulmonary function gain from 15 to 18 years of age in a birth cohort in Brazil. J Phys Act Health 13(11): 1164-1173.

8. Menezes AM, Wehrmeister FC, Muniz LC, Perez Padilla R, Noal RB, et al. (2012) Physical activity and lung function in adolescents: the 1993 Pelotas (Brazil) birth cohort study. J Adolesc Health 51(6): S27-S30.

9. Trabelsi Y, Pariès J, Harrabi I (2008) Factors affecting the development of lung function in Tunisian children. Am J Hum Biol 20(6): 716-725.

10. Kamal M Awad, Aamir Magzob, Omer Elbedri, Omer A Musa (2017) Effect of police training on some cardiopulmonary and hematological parameters) Effect of police training on some cardiopulmonary and hematological parameters. Int SRMS 5: 6.

11. Segizbaeva Mo, Timofeev NN, Donina ZhA, Kuryanovich EN (2015) Aleksandrova NP Effect of inspiratory muscle training on resistance to fatigue of respiratory muscles during exhaustive exercise. Adv Exp Med Biol 840: 35-43.

12. Department of physical education, Branch Rasht, Islamic Azad University, Rasht, Iran (2011) Effect of one period of training on hemoglobin, hematocrit and RBC of athlete girls. Annals of biological researches 2(6): 642-644.

13. Convertino VA (1991) Blood volume: its adaptation to endurance training. Med Sci Sports Exerc 23(12): 831-843.

14. Schumacher YO, Schmid A, Grathwohl D, Bultermann D, Berg A. Hematological indicies and iron status in athletes of various sports and performances. Med Sci Sports Exerc 34(5): 869-875.

15. Kratz A, Lewandrowski K, Siegel AJ, Chaun KC, Flood JG, et al. (2002) Effect of marathon running on hematologic and biochemical laboratory parameters, including cardiac markers. Am J Clin Pathol 118(6): 856863.

16. Majumdar P (2005) Physiology of Sports and Exercise. ( $1^{\text {st }}$ edn), New Central Book Agency, Kolkata, India.

17. Guyton CA, John EH (2006) Text Book of Physiology. (11 ${ }^{\text {th }}$ edn), Elsevier, Pennsylvania.

18. Khurana I (2006) Text Book of Physiology. (1 ${ }^{\text {st }}$ edn) Elsevier, Pennsylvania. 


\section{Your next submission with Juniper Publishers} will reach you the below assets

- Quality Editorial service

- Swift Peer Review

- Reprints availability

- E-prints Service

- Manuscript Podcast for convenient understanding

- Global attainment for your research

- Manuscript accessibility in different formats

(Pdf, E-pub, Full Text, Audio)

- Unceasing customer service

Track the below URL for one-step submission https://juniperpublishers.com/online-submission.php 